\title{
Sewage Quality Assessment of Various Places in Bilaspur City
}

\author{
Ashish Kumar Parashar \\ Faculty of Civil Engineering, Institute of Technology, Central University, Bilaspur, Chhattisgarh, India
}

\begin{abstract}
The quantity, strength and type of sewage depends upon the population, Life style of people and the existence of different types of industries respectively and the amount of treatment required to be given to sewage depends very much upon the source of disposal. In Bilaspur the source of disposal of municipal as well as industrial waste water is Arpa River (Non perennial) which is known as life line of Bilaspur city. The climatic change has already turned the perennial Arpa River into non Perennial River and at this time the Urbanization, Industrial growth and improved standard of living of people of Bilaspur have increased the strength and quantity of sewage in recent years to a point where dilution alone can no longer be relied upon to prevent the undesirable effect of pollution. Hence it is absolutely necessary to study the characteristics and behavior of sewage, to ensure its safe disposal. This study will help us in determining the degree and type of treatment required to a given sewage according to its characteristics and thus to avoid the pollution of the source of its disposal i.e. Arpa river so that the adverse effect of pollution on human health, aquatic life, animals and plants can be eliminated. For the present study we have selected 4 places in Bilaspur City for collection of sewage hence Sample 1 was collected at Vasant Vihar S.E.C.L. Colony, The sample 2 was collected from M/S Narmada Drinks Pvt. Ltd. Sirgitti, The sample 3 was collected at Pachrighat drain. The sample 4 was collected from Nalla near Bannak Chowk Sirgitti. The Chemical tests namely Suspended Solids, Dissolved Solids, Chloride Content, Chemical Oxygen Demand and Physical tests namely $\mathrm{pH}$ value, Temperature, Threshold Odour Number (TON) had been performed and the tests results were compared with Indian standards permissible limits. Priority of this journal is to provide our important and valuable information to all people who show interest. The test results indicated that the Sample-1Vasant Vihar is less polluted, Sample-2 Narmada Drinks only requires neutralization of Chloride Content, Sample-3 Pachrighat was polluted and required treatment in summer season for reducing Solids whereas Sample-4 Bannak Nalla was highly polluted and required throughout treatment of higher degree. Out of the four samples the Sample-4 (Nalla near Bannak Chowk) was found to be most polluted sample in terms of Suspended solids, Chloride content, C.O.D., B.O.D. \& T.O.N. and the drain containing this sample is being used by local public and is being discharged untreated into Arpa River. This Wastewater must be treated to prevent the Environment and the water bodies.
\end{abstract}

Keywords: Water Quality, Water Purification, Wastewater Treatment, C.O.D., B.O.D., Odour Number.

\section{Introduction}

When untreated sewage is discharged into some river stream, floating solids present in the discharged sewage may be washed up on to the shore, near the point of disposal, where they decompose and create foul smell and bad odour. The large amount of organic matter present in the discharged sewage also consume the dissolved oxygen from the river stream, causing fish kills and other undesirable effects. In addition to these

* Corresponding author.

E-mail: aparashar08@gmail.com

(C) 2015 International Association for Sharing Knowledge and Sustainability

DOI: $10.5383 /$ swes.7.02.008 effects, the discharged sewage will contaminate the river water with pathogenic* bacteria.

Hence, even though municipal sewage is $99.9 \%$ water, it requires treatment, if nuisance is to be avoided. The extent and type of treatment required, however, depends upon the character and quality of both sewage and source of disposal. For example, a small community at the seaside might discharge its untreated sewage directly into the ocean without any ill effects, but if the city were located inland on a small stream, a high degree of treatment might be needed, and which type of treatment will be needed will depend upon the chemical and physical characteristics of sewage 
In the olden times, the waste waters from a community were not so much contaminated as they are today. The urbanization, industrial growth, and the improved standards of living, have increased the strength and quantity of municipal sewage in recent years to a point where DILUTION alone can no longer be relied upon to prevent undesirable effects of pollution. In many cases, more advanced treatment of wastewater is essential to prevent undue pollution. This is much more so, when the disposed sewage is likely to contain industrial wastewaters.

Hence, it is absolutely necessary to study the characteristics and behavior of sewage, to ensure its safe disposal. This study will help us in determining the degree and type of treatment required to be given to a particular sewage, and thus to avoid the pollution of the source of its disposal.

\subsection{Waste water Characterization}

In order to dispose treated wastewater, we must have to consider the nature of the wastewater because the effluent quality depends upon the influent characteristics. The treatment capacity and treatment efficiency of treatment systems are calculated based upon the influent concentrations and the effluent requirements.

Efficiency $=[($ Cin - Cout $) /$ Cin $] 100$

Where:

Cin $=$ Influent concentration (typically $\mathrm{mg} / \mathrm{L}$ )

Cout $=$ Effluent concentration (typically $\mathrm{mg} / \mathrm{L}$ )

And Efficiency is expressed as a percentage $(\%)$

Also, the treatment capacity over time for biochemical processes is usually modeled as a first-order equation such that

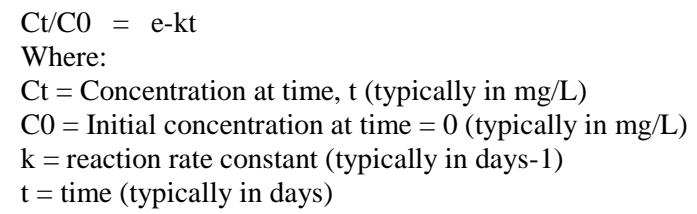

For the purposes of explaining the importance of wastewater characteristics here, the ideas that the wastewater strength (concentration of contaminants), availability of the contaminants as a food source, and the characteristic of being easily metabolized or being difficult to metabolize are all important factors to be considered for designing the treatment processes.

\subsection{Chemical Characterization of Sewage}

Tests conducted for determining the chemical characteristics of sewage help in indicating

The stage of sewage decomposition ;

Strength of sewage ;

Impact on Environment

Type of treatment required for making it safe to the point of disposal. Chemical analysis is therefore, carried out on sewage in order to determine its Chemical Characteristics. It includes TESTS for determining:

Total solids, suspended solids, and settle able solids; $\mathrm{pH}$ value :

Chloride Content ;

Nitrogen Content ;
Presence of Fats, Oil and Grease ; Sulphides, Sulphates and H2S gas ;

Dissolved Oxygen ;

Chemical Oxygen Demand ;

Bio-chemical Oxygen Demand;

While the Physical Characterization involves following:

Tests :

Temperature

Odour

Turbidity

Color

1.3 Various Applications of Treated Waste Effluent The different sustainable ways of disposing the treated wastewater are discussed below.

\subsubsection{Application on Land for Ground Water Recharge}

Recharge of groundwater is one of the ways of reusing wastewater particularly since the groundwater table tends to lower. A crack-free, $3 \mathrm{~m}$ thick soil layer above groundwater is sufficient to prevent organic pollution. Pollution by mineral deposition is far more frequent, as salts like nitrate and phosphate being soluble in water cannot be removed by physical filtration when passing through soil or sand layers.

\subsubsection{Application on Land for Irrigation}

Treated wastewater, if handled properly, can be of high value as it contains several nutrients and is a vital source of fertilizer, hence Treated domestic wastewater is ideal for irrigating community parks, flower beds in gardens and other farm lands/agricultural areas. For an irrigation rate of $2 \mathrm{~m}$ per year $(20,000 \mathrm{cum} / \mathrm{ha})$ which is commonly required for Hyderabad (semi-arid areas), even well-treated wastewater with concentrations as $15 \mathrm{mg} / \mathrm{l}$ of total nitrogen and $3 \mathrm{mg} / \mathrm{l}$ total phosphorous provides $300 \mathrm{~kg} \mathrm{~N}$ and $60 \mathrm{~kg} /$ hectare via irrigation without additional cost; at the same time the same amount of groundwater is saved.

\subsubsection{Discharge into Lakes/Ponds/Water Bodies}

Wastewater is full of nutrients, which can directly be used by algae, water plants and lower animals, which then could become fish feed. Hyderabad is famous for its beautiful lakes. In all, there were more than 150 lakes in Hyderabad Metropolitan Area. But due to the development most of the lakes disappeared. In the Draft Master Plan for 2020, it is proposed to increase the area of water bodies to $95.44 \mathrm{sq}$. km. from the existing $84.3 \mathrm{sq}$. $\mathrm{km}$. One way of achieving this is by channeling all our treated water, storm water etc into the closest lake in the vicinity.

\subsubsection{Use of Treated Waste Water for Construction Activities}

Water if treated up to the required standards can effectively be used for construction purposes. However, it is the general perception noticed among the architects, builders, engineers and other construction companies that the recycled water cannot be used for construction activities viz., mixing, curing, etc due to its hardness and recommend only fresh (soft) water for these purposes. (Cement is mainly composed of tri-calcium silicate, di-calcium silicate, tri-calcium aluminate and tetra-calcium alumina -ferrite formed at a very high temperature in rotary kiln. Some additives such as calcium sulphate are added to impart special properties to it. Hence water with hardness in tune of 400 $\mathrm{mg} / \mathrm{L}$ can be used as calcium carbonate is used for curing the cement). Hence all construction activities use bore water 
(ground water) for this purpose, which is causing severe stress on ground water levels. Bureau of Indian Standards (BIS) have outlined a code for construction water quality (IS 456:2000).

\section{Methodology}

\subsection{Importance of Tests}

\subsubsection{Total Solids, Suspended Solids}

Sewage generally contain very small amount of solids in relation to the huge quantity of water $(99.9 \%)$. As a general rule, the presence of inorganic solids in sewage is not harmful. They require only mechanical appliances for their removal in the treatment plant. On the other hand, suspended and dissolved organic solids are responsible for creating nuisance, if disposed of untreated. The amount of various kinds of Solids helps in determining the Strength of Sewage as follows:

Table 1 - Strength of Sewage for Samples

\begin{tabular}{lccc}
\hline Types of Solid & \multicolumn{3}{c}{ Strength of Sewage } \\
\cline { 2 - 4 } & Weak & Weak & Weak \\
\hline Total Solids & 400 & 400 & 400 \\
& & & \\
\hline Suspended Solids & & & \\
1. Total & 100 & 100 & 100 \\
2. Volatile & 75 & 75 & 75 \\
\hline Settleable Solids & 2.5 & 2.5 & 2.5 \\
\hline Fats, Oil and Grease & 6 & 6 & 6 \\
\hline
\end{tabular}

\subsection{2. pH Value}

The determination of $\mathrm{pH}$ value of sewage is important because of the fact that efficiency of certain treatment methods depends upon the availability of a suitable $\mathrm{pH}$ value. The ph value can be measured quickly and automatically with the help of the potentiometer. The fresh sewage is generally alkaline in nature with ph more than 7 but as time passes, its $\mathrm{pH}$ tends to fall due to production of acid by bacterial action in an aerobic or nitrification processes. The $\mathrm{pH}$ however rises upon the treatment of sewage.

\subsubsection{Chloride Contents}

Chlorides are generally found present in municipal sewage and derive from the kitchen wastes, human feces and urinary discharges etc. The normal chloride content of domestic sewage is $120 \mathrm{mg} / \mathrm{l}$ whereas, the permissible chloride content for water supplies is $250 \mathrm{mg} / 1$.Hence the chloride content of a given sewage is found to be high, it indicates the presence of industrial wastes or infiltration of sea water, there by indicating the strength of sewage.

\subsubsection{Nitrogen Contents}

The presence of nitrogen in sewage indicates the presence of organic matter, and may occur in one or more of the following forms:

Free ammonia

Albuminoidal

Nitrogen

Nitrites

Nitrates
The amount of free ammonia present in sewage can be easily measured by simply boiling the sewage, and measuring the ammonia gas which is consequently liberated. The amount of nitrites or nitrate presents in sewage sample can be measured by color matching methods.

\subsubsection{Presence of Fats, Oils and Greases}

Greases, fats and oils are derived in sewage from the discharges of animals and vegetable matter, or from the industries like garages, kitchens of hotel and restaurants, etc. Such matter from the scum on the top of the sedimentation tanks and clog the voids of the filtering media. They thus interfere with the normal treatment methods and hence need proper detection and removal.

2.1.6. Sulphides, Sulphates and Hydrogen Sulphide Gas Sulphides and Sulphates are formed due to the decomposition of various sulphur containing substances present in sewage. This decomposition also leads to evolution of hydrogen sulphide gas, causing bad smells and odors, besides causing corrosion of concrete sewer pipes.The quantity of Hydrogen sulphide gas in raw sewage is below 1ppm, obnoxious odors are not felt.

\subsubsection{Dissolved Oxygen}

The determination of dissolved oxygen present in sewage is very important, because while discharging the treated sewage into some river stream, it is necessary to ensure at least 4ppm of DO in it, as otherwise, fish are likely to be killed, creating nuisance near the vicinity of disposal. The DO test performed on sewage before treatment, helps in indicating the condition of sewage. It is well known that only very fresh sewage contains some dissolved oxygen, which is soon depleted by aerobic decomposition. Also, the dissolved oxygen in fresh sewage depends upon temperature. If the temperature of sewage is more the DO content will be less. The solubility of oxygen in sewage is $95 \%$ of that in distilled water.

\subsubsection{Chemical Oxygen Demand}

The oxygen required to oxidize the organic matter present in a given waste water can be theoretically computed, if the organics present in waste water are known. The COD of a raw water or a waste water is, therefore, determined by performing a laboratory test on the given water with a strong oxidant like dichromate solution.

\subsubsection{Bio Chemical Oxygen Demand}

The organic matter, in fact is of two types that is which is biologically oxidized is called biologically active and that which cannot be oxidized biologically is called biologically inactive. While testing a waste water, we are interested in finding out the amount of biologically active organic matter present in it, whereas the COD test give us the total of biologically active as well as biologically inactive organic matter. Hence, further testing is carried out to determine the BOD of sewage, which directly gives us the amount of biologically active organic matter present in sewage. If sufficient oxygen is available in waste water, the useful aerobic bacteria will flourish and cause the aerobic biological decomposition if waste water, which will continue until oxidation is complicated. The amount of oxygen consumed in this process is the BOD.

Polluted waters will continue to absorb oxygen for many months, and it is not practically feasible to determine this ultimate oxygen demand. Hence, the BOD of water during 5 days $20^{\circ} \mathrm{C}$ is generally taken as the standard demand, and is about $68 \%$ of the total demand. A 10day BOD is about $90 \%$ of the total. 


\section{Sample Collection}

\subsection{Places of Collection of Samples}

\subsubsection{Sample Number 1. Vasant Vihar Colony}

The sample is taken from the inlet of the Waste effluent treatment plant of Vasant Vihar which is a residential colony of S.E.C.L. BILASPUR employees. The waste water drains out from this colony is treated at D.E.T.P. (DOMESTIC EFFLUENT TREATMENT PLANT) which is situated in Vasant Vihar Colony. The waste water contains Domestic waste only as it is a residential colony and no other industry is discharging their Waste Effluent into the drain of Vasant Vihar. The treated waste water from DETP plant discharges its effluent at Pachrighat through its drains.

\subsubsection{Sample Number 2. M/S Narmada Drinks Pvt. Ltd. I/A Sirgitti}

M/S Narmada drinks Pvt. Ltd. Is a cold drink industry situated in Sirgitti near Bannak Chowk in Bilaspur. The purpose of testing its waste effluent is to know how much pollution it is giving to the local environment besides the production of cold drinks The discharge effluent of this industry is free from Odour and Color but may be contaminated with certain harmful ingredients like Nitrogen and other harmful compounds.

\subsubsection{Sample Number 3. Pachrighat (Arpa river basin) Sanichari Rapta}

Pachrighat is situated near Sanichari Rapta ( Arpa river ), Golbazar market in Bilaspur. It is a discharging point of Municipal Sewer Drains which runs in Bilaspur. This drain includes domestic as well as industrial wastes as it crosses Nehru Nagar, Vhrihaspati market, Golbazar market, SIMS, and other landmarks of Bilaspur. Hence this is the reason that the Waste Water draining from this must contain both the Industrial and Domestic wastes. The local people over there are using Arpa River for their domestic uses like bathing and watering of vegetations. The place from where they use water from River is very closer to the point of disposal.

\subsubsection{Sample Number 4. Bannak Nalla, Bannak Chowk Sirgitti}

Sirgitti is a well known industrial area of Bilaspur district; here various industries like M/S Narmada Drinks Pvt. Ltd., Om Oils, Golchha Oxides, Vandana Power Plant and many other industries are situated. These industries are discharging their treated waste effluent into a small stream flowing nearby. The local public uses that stream for their domestic purpose. The purpose of sampling this stream is to study the ingredient $s$ present in mixed industrial sewage, The degree of treatment given by the industries the effect of wastewater on Environment $\&$ treatment required for the sewage disposed by above mentioned industries.

\subsection{Physical Characteristics of Samples}

The samples are collected in Winter Season between nov-2011 to jan-2012 and the physical as well as the Chemical Characterization test results is subjected to seasonal variation. However at the time of sampling the samples are found with the following Physical Characteristics.
Table 2 - Types of Solids

\begin{tabular}{lllll}
\hline $\begin{array}{l}\text { Sample } \\
\text { No. }\end{array}$ & $\begin{array}{l}\text { Name of } \\
\text { sample }\end{array}$ & S1 & S2 & S3 = S1- S2 \\
\hline 1 & Vasant Vihar & 1770 & 1080 & 690 \\
\hline 2 & $\begin{array}{l}\text { Narmada } \\
\text { Drinks }\end{array}$ & 1268 & 60 & 1208 \\
\hline 3 & Pachrighat & 2110 & 1280 & 830 \\
\hline 4 & Bannak Nalla & 2440 & 1320 & 1120 \\
\hline
\end{tabular}

Analysis of solids (Unit mg/liter)

Here:-

$\mathrm{S} 1=$ total solids present in sample got by evaporating $100 \mathrm{ml}$ of sample and then weighting the dry residual left.

S2 $=$ total filterable or suspended solids present in sample got by filtering it through filter paper and then weighting the dry residual left on filter paper.

S3 = total amount of dissolved solids present in sample got simply by subtracting total solids $\mathrm{S} 1$ from total suspended solids present in that sample.

Note: the total amount of solids present in sewage depends upon season for rainy season the contamination per liter will be less and vice versa for summer season.

Table 3 - Test for Chloride Content

\begin{tabular}{llllll}
\hline S.NO. & $\begin{array}{l}\text { Volume of } \\
\text { AgNO3 }\end{array}$ & \multicolumn{4}{c}{$\begin{array}{l}\text { Titrate Volume of AgNO3 } \\
\text { for samples(V2) }\end{array}$} \\
\cline { 2 - 6 } & $\begin{array}{l}\text { Initial } \\
\text { Volume }\end{array}$ & $\begin{array}{l}\text { Vasant } \\
\text { Vihar }\end{array}$ & $\begin{array}{l}\text { Narmada } \\
\text { Drinks }\end{array}$ & Pachrighat & $\begin{array}{l}\text { Bannak } \\
\text { Nalla }\end{array}$ \\
\hline 1 & 50 & 18.2 & 26.4 & 19.9 & 27.1 \\
\hline 2 & 50 & 18.2 & 26.1 & 19.7 & 27.1 \\
\hline 3 & 50 & 18.0 & 26.4 & 19.9 & 27.3 \\
\hline Final & & 18.2 & 26.4 & 19.9 & 25.9 \\
volume & & & & & \\
\hline
\end{tabular}

Formula for Calculation of Chloride Content: N1V1=N2V2

Where

$\mathrm{N} 1=$ normality of sample,

$\mathrm{N} 2=$ blank corrected normality of $\mathrm{AgNO} 3$

$\mathrm{V} 1=$ volume of sample taken,

$\mathrm{V} 2=$ titrate volume of $\mathrm{AgNO} 3$ Hence

$\mathrm{N} 1=\mathrm{N} 2 \mathrm{~V} 2 / \mathrm{V} 1$

Now strength of chloride $=$ normality of sample (N1) X Eq. wt. of Cl-(35.45 grams/litre)

Volume of sample taken $(\mathrm{V} 1)=50 \mathrm{ml}$. for each.

Table 4 - Chloride Content for Samples

\begin{tabular}{llll}
\hline $\begin{array}{l}\text { S.NO. } \\
\text { Name of } \\
\text { sample }\end{array}$ & $\begin{array}{l}\text { Normality of sample Cl- Content } \\
\text { N1=N2V2/V1 }\end{array}$ & $\begin{array}{l}\text { Eq. Wt. of } \\
\text { (in mg/liter) }\end{array}$ \\
\hline & Vasant & $(0.048 \times 18.2) / 50=619.38$ & $35450 \mathrm{mg} / \mathrm{lit}$ \\
1 & & & \\
\hline 2 & Vihar & 0.01747 & \\
\hline
\end{tabular}




\begin{tabular}{llll} 
& Drinks & 0.02534 & \\
\hline 3 & Pachrighat & $(0.048 \times 19.9) / 50=677.24$ & $35450 \mathrm{mg} / \mathrm{lit}$ \\
& 0.01910 & \\
\hline & Barnak & $(0.048 \times 27.1) / 50=922.27$ & $35450 \mathrm{mg} / \mathrm{lit}$ \\
& & & \\
\hline & Nalla & 0.0260 &
\end{tabular}

3.2.3 Calculation of C.O.D.

Volume of $\mathrm{Fe}(\mathrm{NH} 4) 2 \mathrm{SO} 4.6 \mathrm{H} 2 \mathrm{O}$ in blank sample $\mathrm{V} 1=11.2 \mathrm{ml}$

Table 5 - C.O.D. for Samples

\begin{tabular}{rlcll}
\hline $\begin{array}{l}\text { Sample } \\
\text { NO. }\end{array}$ & $\begin{array}{l}\text { Name of } \\
\text { sample }\end{array}$ & $\begin{array}{l}\text { Volume of } \\
\text { sample taken } \\
\mathrm{X}(\mathrm{ml} .)\end{array}$ & $\begin{array}{l}\text { Titrate Volume of } \\
\text { Fe(NH4)2SO4.6 } \\
\mathrm{H} 2 \mathrm{O} \\
\mathrm{V} 2(\mathrm{ml})\end{array}$ & $\begin{array}{l}\text { C.O.D. of } \\
\text { Sample } \\
(\mathrm{mg} / \mathrm{lit})\end{array}$ \\
\hline $\begin{array}{llll}\text { Vasant } \\
\text { Vihar }\end{array}$ & 20 & 10.2 & 98 \\
\hline 2 & $\begin{array}{l}\text { Narmada } \\
\text { Drinks }\end{array}$ & 20 & 10.1 & 107.8 \\
\hline 3 & Pachrighat & 20 & 9.2 & 196 \\
\hline 4 & $\begin{array}{l}\text { Barnak } \\
\text { Nalla }\end{array}$ & 2 & 9.9 & 1274 \\
\hline
\end{tabular}

Here: $\mathrm{V}_{1}-$ Volume of the $\mathrm{Fe}\left(\mathrm{NH}_{4}\right) 2 \mathrm{SO}_{4} \cdot 6 \mathrm{H}_{2} \mathrm{O}$ run down in the blank experiment

$\mathrm{V}_{2}-$ Volume of the $\mathrm{Fe}\left(\mathrm{NH}_{4}\right) 2 \mathrm{SO}_{4} .6 \mathrm{H}_{2} \mathrm{O}$ run down in the test experiment of sample

$\mathrm{X}$ - Volume of test sample taken

$\mathrm{N}$-Normality of

$\mathrm{Fe}\left(\mathrm{NH}_{4}\right) 2 \mathrm{SO}_{4} .6 \mathrm{H}_{2} \mathrm{O}$ solution i.e.

0.245

Obtained Value of C.O.D. of Samples:

\subsubsection{Calculation of B.O.D.}

The B.O.D. of a sewage sample can be estimated with the help of B.O.D. /C.O.D. ratio. Since the BOD5 is measured which is about $68 \%$ of BODu, we can easily state that BOD5/COD ratio should, for fully-biodegradable waste water vary between 0.92 x $0.68=0.63$ to $1.0 \times 0.68=0.68$. Any waste water having its $\mathrm{BOD} / \mathrm{COD}$ ratio more than 0.63 , can hence, be considered to be quite amenable to biological treatment, since it does not contain non-biodegradable organics. So here for our project purpose to predict the BOD5 it will be convenient to take BOD/COD ratio as 0.58 because samples are contaminated with some amount of fixed solids also.

B.O.D. Estimation of Samples

Table-6 B.O.D. for Samples

\begin{tabular}{ccccc}
\hline $\begin{array}{c}\text { Sample } \\
\text { Name }\end{array}$ & $\begin{array}{c}\text { Vasant } \\
\text { Vihar }\end{array}$ & $\begin{array}{c}\text { Narmada } \\
\text { Drinks }\end{array}$ & Pachrihat & $\begin{array}{c}\text { Bannak } \\
\text { Nalla }\end{array}$ \\
\hline B.O.D. & 65.84 & 62.52 & 113.68 & 738.92 \\
\hline
\end{tabular}

\subsubsection{Calculation of TON (THRESHOLD ODOUR NUMBER)}

Table-7 TON for Samples

\begin{tabular}{llccc}
\hline $\begin{array}{l}\text { Sample } \\
\text { No. }\end{array}$ & $\begin{array}{l}\text { Name of } \\
\text { Sample }\end{array}$ & $\begin{array}{c}\text { Vs } \\
\text { (in ml.) }\end{array}$ & $\begin{array}{c}\text { VD } \\
\text { (in ml.) }\end{array}$ & TON \\
\hline \multicolumn{1}{r}{1} & Vasant Vihar & 20 & 86 & 5.3
\end{tabular}

\begin{tabular}{clccc}
\hline 2 & Narmada & 20 & 0 & 0 \\
& Drinks & & & \\
\hline 3 & Pachrighat & 20 & 99 & 5.95 \\
\hline 4 & Bannak Nalla & 20 & 970 & 49.5 \\
\hline
\end{tabular}

$\mathrm{Vs}=$ volume of the sewage sample

$\mathrm{V}_{\mathrm{D}}=$ volume of the distilled water added to the sewage sample just to make it odourless

$\mathrm{TON}=$ the extent of dilution required to just make the sample free of odour. it is given by the formula $\mathrm{TON}=$

$\left(V_{s}+V_{D}\right) / V_{s}$

\section{RESULTS}

IS:2490- Tolerance Limits For Industrial Effluent Discharge Into Inland Surface Water.

IS: 3306 - Tolerance Limits For Industrial Effluents Discharge Into Public Sewer Discharge.

IS: 3307 - Tolerance Limits For Various Polluting Constituents Of Waste-Water Effluent For Their Discharge On Land For Irrigation.

Table-8 Standard Limits for Various Tests

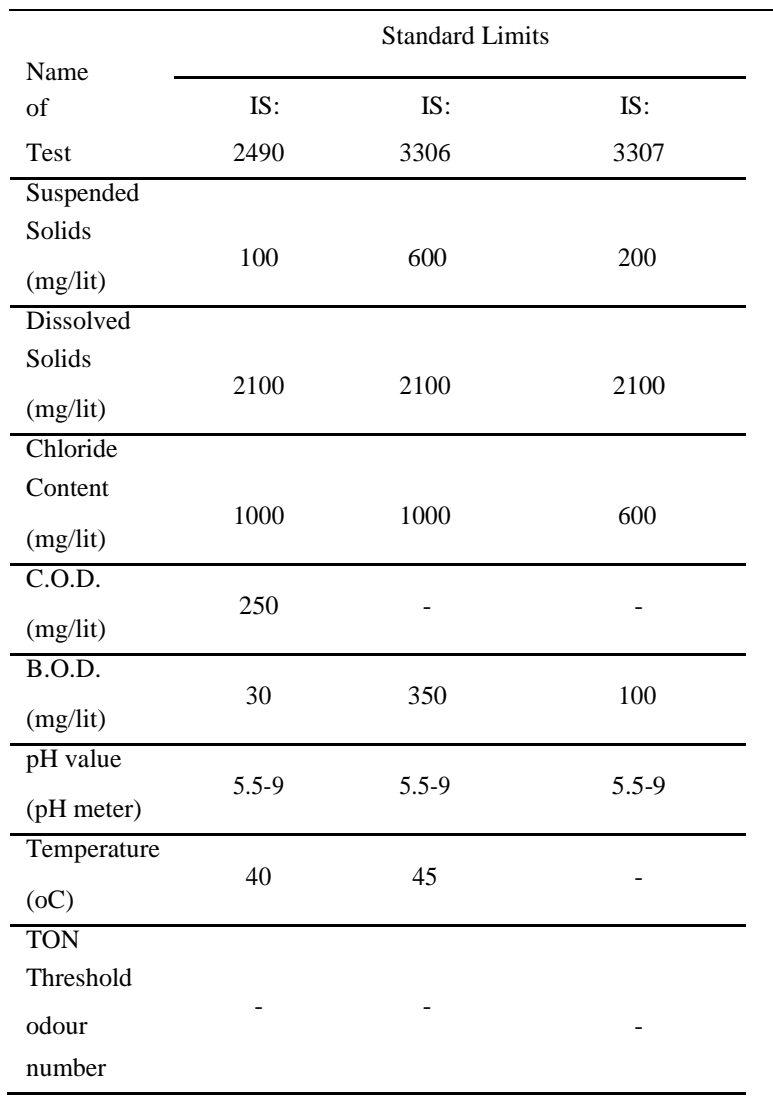


Table 9: Test Result for Subject

\begin{tabular}{|c|c|c|c|c|}
\hline & Vasant & Narmada & Pachri & Bannak \\
\hline \multicolumn{5}{|l|}{ Name } \\
\hline & Vihar & Drinks & Ghat & Nalla \\
\hline \multicolumn{5}{|l|}{ of } \\
\hline & Sample & Sample & Sample & Sample \\
\hline \multicolumn{5}{|l|}{ Test } \\
\hline & 1 & 2 & 3 & 4 \\
\hline \multicolumn{5}{|l|}{ Suspended } \\
\hline \multicolumn{5}{|l|}{ Solids } \\
\hline & 1080.0 & 60.0 & 1280.0 & 1320.0 \\
\hline \multicolumn{5}{|l|}{ (mg/lit) } \\
\hline \multicolumn{5}{|l|}{ Dissolved } \\
\hline \multicolumn{5}{|l|}{ Solids } \\
\hline & 690.0 & 1208.0 & 830.0 & 1420.0 \\
\hline \multicolumn{5}{|l|}{ (mg/lit) } \\
\hline \multicolumn{5}{|l|}{ Chloride } \\
\hline \multicolumn{5}{|l|}{ Content } \\
\hline & 619.38 & 898.44 & 677.24 & 922.27 \\
\hline \multicolumn{5}{|l|}{ (mg/lit) } \\
\hline \multicolumn{5}{|l|}{ C.O.D. } \\
\hline & 98 & 107.8 & 196 & 1274 \\
\hline \multicolumn{5}{|l|}{ (mg/lit) } \\
\hline \multicolumn{5}{|l|}{ B.O.D. } \\
\hline & 56.84 & 62.52 & 113.68 & 738.92 \\
\hline \multicolumn{5}{|l|}{ (mg/lit) } \\
\hline \multicolumn{5}{|l|}{$\mathrm{pH}$ value } \\
\hline & 5 & 8.5 & 5 & 8 \\
\hline \multicolumn{5}{|l|}{ (pH meter) } \\
\hline \multicolumn{5}{|l|}{ Temperature } \\
\hline & 28 & 27 & 27 & 28 \\
\hline \multicolumn{5}{|l|}{ (oC) } \\
\hline \multicolumn{5}{|l|}{ TON } \\
\hline $\begin{array}{l}\text { Threshold } \\
\text { odour number }\end{array}$ & 5.3 & 0 & 5.95 & 49.5 \\
\hline
\end{tabular}

\section{Conclusion}

In Present Study, the sewage sample of four places namely 1. Vasant Vihar, 2. Narmada drinks, 3. Pachrighat and 4. Bannak Nalla had been tested and the test results were compared with the B.I.S. standards. The following results were obtained:- The Suspended Solids (in $\mathrm{mg} / \mathrm{liter}$ ) of samples were found to be 1080, 60, 1280 and 1320 for Vasant Vihar, Narmada drinks, Pachrighat and Bannak Nalla respectively. The Dissolved Solids (in $\mathrm{mg} / \mathrm{liter}$ ) of samples were found to be 690, 1208, 830 and 1120 for Vasant Vihar, Narmada drinks, Pachrighat and Bannak Nalla respectively.

The Chloride Content (in $\mathrm{mg} / \mathrm{liter}$ ) of samples were found to be 619.38, 898.44, 677.24 and 922.27 for Vasant Vihar, Narmada drinks, Pachrighat and Bannak Nalla respectively. The C.O.D. (in $\mathrm{mg} / \mathrm{liter}$ ) of samples were found to be 98, 107.8, 196 and 1274 respectively for Vasant Vihar, Narmada drinks, Pachrighat and Bannak Nalla. The B.O.D. (in $\mathrm{mg} / \mathrm{liter}$ ) of samples were found to be 56.84, 62.52, 113.68 and 738.92 respectively for Vasant Vihar, Narmada drinks, Pachrighat and Bannak Nalla. The $\mathrm{pH}$ Value of samples were found to be 5, 8.5, 5 and $8 \mathrm{pH}$ unit respectively for Vasant Vihar, Narmada drinks, Pachrighat and Bannak Nalla.

The T.O.N. (Threshold Odour Number) of samples were found to be 5.3, 0, 5.95 and 49.5 for Vasant Vihar, Narmada drinks, Pachrighat and Bannak Nalla respectively. Thus on the basis of test results and its comparison with the Indian Standards of different categories it can be concluded that among the four samples of wastewater the "Bannak Nalla" is the most polluted stream (carrying Industrial waste of various industries situated nearby in Sirgitti) and discharging wastewater into the Arpa river near Masturi area, and requires advanced treatment.

The Emphasis must be given to make it safe for disposal into Arpa River and should be carried through sewerage system to prevent the Environment. While in case of Municipal wastewater which is discharged into Arpa river near Sanichari Rapta i.e. Vasant Vihar and Pachrighat, Both are not highly contaminated and can be used for Sewage Farming or on land for irrigation after primary treatment, But the wastewater will require emphasis on treatment in summer season. 


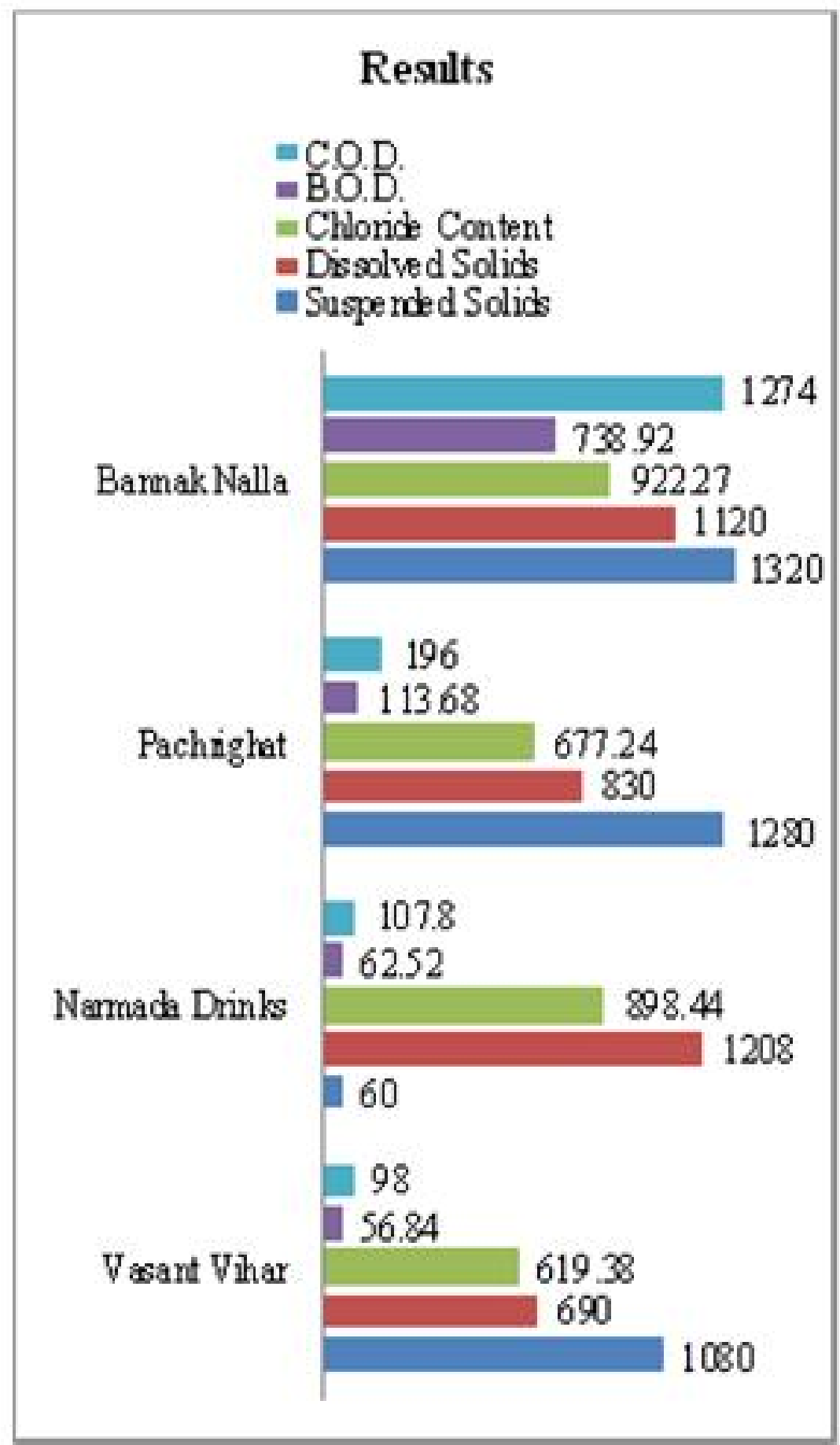

Fig. 1. Graphical Representation of Results 


\section{References}

[1] American Public Health Association (APHA), Standard methods for the Analysis, 7th Edn., University Press, Washington DC, New York, USA (1989)

[2] Bouwer H., Renovation of wastewater with rapid infiltration land treatment system, In: Asano T. (Ed.), Artificial Recharge of Groundwater, Butterworth, Boston, 249-282 (1985)

[3] Bahgat M., Dewedar M.A. and Zayed A., Sand-Filters used for wastewater treatment: build up and distribution of microorganisms, Water Res., (33), 19491955 (1999)

[4] Banks, David, Paul L. Younger, Rolf-Tore Arnesen, Egil R. Iversen and S. B. Banks. 1997. Mine-water chemistry: the good, the bad and the ugly. Environmental Geology 32: 157-174.

[5] Cochran, W.G. 1963 Sampling Techniques. Second edition. Wiley and Sons, New York,413 pp.

[6] Fatoki S.O., Gogwana P. and Ogunfowokan A.O., Pollution assessment in the Keiskamma River and in the impoundmen downstream, Water SA., 29, 183-187 (2003)

[7] Grady C.P.L. and Daigger G.T., Biological Wastewater Treatment, Theory and Application, Marcel Dekker, Inc. New York, NY (1997)

[8] Government Gazette, Requirements for the purification of wastewater or effluent, Gazette No. 9225, Regulation, 991 (1984)

[9] Gilbert, R.O. 1987 Statistical Methods for Environmental Pollution Monitoring. Van Nostrand Reinhold Company, New York, 320 pp.

[10] Jenssen P.D. and Siegrist R.L., Technology assessment of wastewater treatment by soil infiltration systems, Water Sci. Technol, 22(3/4), 83-93 (1990)

[11] Morrison G., Fatoki O.S., Persson L. and Ekberg A., Assessment of the impact of point source pollution from the Keiskammahoek Sewage Treatment Plant on the Keiskamma River-pH, electrical conductivity, oxygen demanding substance (COD) and nutrients, Water SA., 27(4), 475-480 (2001)
[12] North American Freshwater Fauna. Conservation Biology 13: 1220-1222. Sachs, J. D. (2001). Macroeconomics and health: Investing in health for economic development. Report of the Commission on Macroeconomics and Health, prepared for WHO.

[14] Perks A.R., Bauer G.A., Devnani S. and Bhambane E., Wastewater flow monitoring for Mumbai, India, Internal Report for R.V. Anderson Associates Ltd., Ottawa, Canada, 1-6 (2004)

[15] People, Water for Life. UNESCO: Paris, France. UN WWAP. 2006. United Nations World Water Assessment Programme. The World Water Development Report 2: Water, A Shared Responsibility. UNESCO: Paris, France.

[16] Raskin, P. Suttonkk, and M.van den Belt. (1997). The value of the world's ecosystem services and natural capital. Nature, 387:353-360. FAO 1996. Food and Agriculture Organization of the United Nations.

[17] Schudel P. and Boller M., Onsite wastewater treatment with intermittent buried filters, Water Sci. Technol, 22(3/4), 93-100 (1990)

[18] Thornton, K.W., Kennedy, R.H., Magoun, A.D. and Saul, G.E. 1982 Reservoir water quality sampling design. Water Resources Bull., 18, 471-480.

[19] Tarundeep G., Performance monitoring and evaluation of Sewage Treatment Plantsbased on UASB - Facultative pond $\mathrm{Ph}$. D Thesis, Department of Biotechnology and Environment Sciences Thapar University (Punjab) (2010)

[20] United Nations Environment Programme (UNEP). (1996). Groundwater: a threatened resource. UNEP Environment

Library No. 15, UNEP, Nairobi, Kenya.

[21] Ward, M.H., S.D. Mark, K.P. Cantor, D.D. Weisenburger, A. Correa-Villaseñor, and S.H. Zahm. (1996). Drinking water nitrate and the risk of non-Hodgkin's lymphoma. Epidemiology 7:465-471.

[22] WHO, Guideline for Drinking Water Quality, Vol 1: Recommendations. World Health Organization (WHO),

Geneva, WHO, (1989), Health guidelines for use of wastewater in agriculture and aquaculture, World Health Organization (1993)

[23]Weyer, P.J., J.R. Cerhan, B.C. Kross, G.R. Hallberg, J. Kantamneni, G. Breuer, M.P. Jones, W. Zheng, and C.F. Lynch. (2001). Municipal drinking water nitrate level and cancer risk in older women: The Iowa women's health study. Epidemiology 11:327-338 